\title{
Implementation of School-Based Management at State Elementary School 3 Makarti Jaya in the Era of Industrial Revolution 4.0
}

\author{
Munadi $^{1 *)}$, Edi Harapan ${ }^{2}$, Tahrun $^{2}$
}

\author{
${ }^{1}$ SDN 3 Makarti Jaya \\ ${ }^{2}$ Universitas PGRI Palembang \\ *Corresponding author. Email: munadicakep78@gmail.com
}

\begin{abstract}
This study aims to identify and describe knowing and describing the implementation of school-based management at the State Elementary School 3 of Makarti Jaya in the industrial revolution of the era 4.0, in terms of curriculum management, student management, infrastructure management, teacher quality management and the obstacles faced. Research of the data collection techniques: 1) observation, 2) interviews, 3) documentation. The data analysis techniques: 1) the data reduction, 2) the data presentation, 3) the data verification. The results of this study indicate that: (1) in terms of curriculum management, it can be said to be good, where the implementation is in accordance with the established curriculum; (2) in terms of infrastructure management, it can be said to be good, which has made every effort to completed the existing needs; (3) in terms of students management it can be said that it is good, where education management is implemented by recording all the number of students at the State Elementary School 3 of Makarti Jaya; (4) In terms of teacher quality management, it can be said to be good, where the number of teachers at the State Elementary School 3 of Makarti Jaya for 2020/2021 is 18 teachers, consisting of 11 government employees teachers and 7 honorary teachers. Of the 11 government employees teachers who already have teaching certificates, 10 are government employees teachers $(90.90 \%)$ and 1 government employees teacher $(9.09 \%)$ do not have educator certificates.
\end{abstract}

Keywords: School Based Management, Elementary School, Industrial Revolution 4.0

\section{INTRODUCTION}

The Industrial Revolution 4.0 is one of the implementations of the new German technology 2020 projection, which is carried out by developing production technology, establishing a national policy structure, and so on. Robots, artificial intelligence, machine learning, biotechnology, blockchain, the internet of things (IoT), and driverless cars are all present. Education is closely linked to the Fourth Industrial Revolution, and can be used to promote learning and thought habits, as well as cultivate new and groundbreaking ideas from students, in order to create a superior and competitive next generation.

The word "Industrial Revolution Period Education 4.0" was coined to describe the different ways to incorporate cyber technology into learning, both physically and digitally. Education in the Industrial Revolution Age 4.0 is a phenomenon that adapts a modern curriculum to the present situation in reaction to the needs of the industrial revolution. The curriculum will open a window to the world with your fingertips, such as through the use of the internet of things (IoT). Teachers, on the other hand, gain access to more resources and teaching techniques.

Several reasons for using this approach are as follows: a) the importance of school autonomy, with this autonomy schools will be able to develop schools or madrasahs optimally by seeing their potential while still paying attention to local wisdom; b) Flexible, with SBM schools are more flexible and agile in utilizing school resources; c) with SBM schools will know the strengths, weaknesses, opportunities and threats that exist.

Schools know what needs to be improved, thus schools are able to make programs based on needs and focus on solving existing problems: a) the decision is determined by the school, because the one who knows best about the condition of the school is the school itself 
[1]; b) more efficient use of resources [2]; c) involvement of school and community members (decision making) [3]; d) Schools are responsible for the quality of their respective education to the government [4]; e) Schools can do healthy competition with other schools [5]; f) Schools can quickly respond to community and environmental aspirations.

Efforts to improve the quality of education are carried out using various approaches, both institutional approaches, legal formal, and empowerment of educational resources [6]. One institutional approach is through the establishment of the Directorate General of Quality Improvement of Teachers and Education Personnel (Ditjen PMPTK). A systematic legal approach focused on a set of education-related laws (regulations), such as Law No. 20 of 2003 on the National Education System, Government Regulation No. 19 of 2005 on National Education Standards, and Law of the Republic of Indonesia No. 14 of 2005 on Teachers and Lecturers.

School-based management (SBM) is a model of bureaucratic reform as a consequence of decentralization in the world of education to create a better future school form compared to the previous one. MBS emphasized that the concept refers to resource management at the school level and not at a centralized system or level [7].

The implementation of SBM in schools requires the readiness of various components and educational instruments both internally and externally that can support the implementation of SBM itself, including: school buildings equipped with learning facilities and infrastructure, school principals, educators and education personnel, students, environment school participation of students' parents, community support and other businesses [8]

The main problem of the quality of education at this time is that it relies more on the quality of graduates produced by the education unit itself. In this connection, explains that, in general, quality implies the level of excellence of a product in the form of goods / services, both real and unreal. In connection with the description above, school-based management (SBM) is very important to be implemented in the school environment, because with good school-based management its implementation will be able to contribute to improving the quality of education. The quality of education will not run well without the implementation of good schoolbased management. Meanwhile, at SDN 3 Makarti Jaya, the implementation of school-based management in terms of curriculum management has been carried out in accordance with the applicable curriculum, but it still needs to be addressed so that it will be better in the future. Because so far, the curriculum used has not been optimal. There are still some teachers who use lesson plans, but they are not accompanied by teaching aids. The teacher's handbook is only 1 piece, the teacher should have at least three handbooks. Likewise, the management of infrastructure and facilities still needs to be improved, because there are still several facilities that are no longer suitable for use, such as examples of teaching aids are still lacking, student toilets, student handbooks, teacher books as guidelines for teaching. Teacher quality management, currently SDN 3 Makarti Jaya has a total of 18 teachers consisting of 11 PNS teachers and 7 honorary teachers. Educational staff as many as 4 people. Of the 11 PNS teachers who already have teaching certificates, 5 are PNS teachers $(45.46 \%)$ and 6 PNS teachers $(54.54 \%)$ do not have educator certificates.

Based on the description of the background of the problem above, the researchers still see some shortcomings that need to be addressed at SDN 3 Makarti Jaya by optimizing the implementation of School Based Management that has been implemented so far, through research with the title, "Implementation of School Based Management at SDN 3 Makarti Jaya in the Era Industrial Revolution 4.0. In addition, researchers also saw that no other researchers had conducted research with a similar study. This is what researchers think is necessary to research.

\section{METHODS}

This research design refers to a qualitative research method with a descriptive approach. The descriptive method is a method used to examine the status of a group of people, an object, a set of conditions, a system of thought, or a class of events in the present [9].

\section{RESULTS AND DISCUSSION}

Based on research data on the implementation of school-based management at SDN 3 Makarti Jaya in the era of the industrial revolution 4.0, in terms of curriculum management, student management, facilities and infrastructure management, teacher quality management.

However, before it is fully described, data collection is obtained from: (1) interviews with school principals, (2) interviews with teachers, (3) interviews with administrative staff. Furthermore, the research observation data were obtained from: (1) curriculum management observations; (2) observation of facilities and infrastructure management; (3) student management observation; (4) and teacher quality management observations. In addition, research data were obtained from documentation, which includes: (1) curriculum documentation; (2) documentation of facilities and infrastructure; (3) student documentation; (4) documentation of teacher activities; (5) documentation of interviews with school principals; (6) documentation of researcher interviews with administrative staff; (7) documentation of the researcher interview with the teacher.

Based on research related to the implementation of school-based management at SDN 3 Makarti Jaya in the era of the industrial revolution 4.0, in terms of curriculum management SDN 3 Makarti Jaya has implemented its implementation based on Government 
Regulation Number 32 of 2013 concerning National Education Standards which mandates the compilation of revisions of the unit level curriculum. education to the 2013 curriculum (K-13), which explains the foundation of curriculum preparation, the juridical foundation of the 2013 curriculum, the objectives of preparing the 2013 curriculum, the principles of SD curriculum development, the principles of implementing the K-13 SD curriculum [10]. In the implementation of schoolbased management at SDN 3 Makarti Jaya in the era of the industrial revolution 4.0 , in terms of curriculum management, it has implemented according to Government regulations and aligns with the vision and mission of SDN 3 Makarti Jaya, namely the values of curriculum development, where the values implanted are the values of character education.

\section{CONCLUSION}

The implementation of school-based management at SDN 3 Makarti Jaya in the era of the industrial revolution 4.0, in terms of curriculum management, where the curriculum designed at SDN 3 Makarti Jaya refers to the 2013 curriculum, which adds that the curriculum design includes: (1) Character Education Values; (2) Environmental Education Values; (3) Gender Equality Values; (4) Entrepreneurial Values. The curriculum structure designed at SDN 3 Makarti Jaya, namely: (1) Core competencies, (2) Subjects, (3) Learning Content, (4) Basic Competencies, (5) Learning Load. Furthermore, the curriculum formulation designed at SDN 3 Makarti Jaya includes: (1) Core Competence 1 (KI-1) for the core competence of spiritual attitudes; (2) Core Competence 2 (KI-2) for the core competence of social attitudes; (3) Core Competence 3 (KI-3) for the core competence of knowledge attitudes, and (4) Core Competency 4 (KI-4) for the core competence of attitude skills. Meanwhile, the design compiled in the curriculum management at SDN 3 Makarti Jaya regarding basic competences includes four groups according to the grouping of core competencies, namely as follows. (1) Group 1, the Basic Competency group for spiritual attitudes in order to describe KI-1; (2) Group 2, the Basic Competency group for spiritual attitudes in order to describe KI-2; (3) Group 3, the Basic Competency group for spiritual attitudes in order to describe KI-3; (4) Group 4, the Basic Competency group for spiritual attitudes in order to describe KI-4.

The obstacles faced in the implementation of schoolbased management at SDN 3 Makarti Jaya in the era of the industrial revolution 4.0 , in terms of curriculum management, management of facilities and infrastructure, student management, and teacher quality management. Obstacles to the implementation of school-based management at SDN 3 Makarti Jaya in the era of the industrial revolution 4.0, in terms of curriculum management where the designs that have been made based on the 2013 curriculum that have been determined, not all components can be implemented properly, such as the values of character education have not fully touched the participants students, the values of environmental education have not been implemented properly, where there are still students who often cross the classroom walls. The formulation of KI-1 competence for spiritual attitudes has not been fully implemented properly for students, KI-2 social attitudes have not been fully implemented properly for students. KI-3 knowledge attitude has not been fully implemented properly for students; KI-4 attitude skills have not been fully implemented properly for students.

I would like to thank the Chancellor of the PGRI Palembang University, Postgraduate Director, Head of Education Management Study Program, Thesis Advisor and fellow students of Makarti Jaya Class who have helped me in the preparation of this journal.

\section{REFERENCES}

[1] Rivayanti, Arafat, Y., \& Puspita, Y. (2020). Manajemen Kepemimpinan Kepala Sekolah dalam Pembinaan Profesionalisme Guru . Journal of Innovation in Teaching and Instructional Media, 1(1), 10-17. Retrieved from https://ejournal.karinosseff.org/index.php/jitim/arti cle/view/25

[2] Setio, H. L., Ahmad, S., \& Wahidy, A. (2020). Pengaruh Supervisi Akademik Kepala Sekolah dan Budaya Sekolah Terhadap Mutu Mengajar Guru. Journal of Innovation in Teaching and Instructional Media, 1(1), 90-103. Retrieved from https://ejournal.karinosseff.org/index.php/jitim/arti cle/view/35

[3] Maryani, A., Lian, B., \& Wardarita, R. (2020). Pengaruh Gaya Kepemimpinan Kepala Sekolah dan Budaya Organisasi Sekolah terhadap Kinerja Guru. Journal of Innovation in Teaching and Instructional Media, 1(1), 18-25. Retrieved from https://ejournal.karinosseff.org/index.php/jitim/arti cle/view/26

[4] Comalasari, E., Harapan, E., \& Houtman. (2020). Pengaruh Gaya Kepemimpinan Demokratis Kepala Sekolah, Kompetensi Guru dan Manajemen Kelas Terhadap Mutu Pembelajaran. Journal of Innovation in Teaching and Instructional Media, 1(1), 74-84. Retrieved from https://ejournal.karinosseff.org/index.php/jitim/arti cle/view/31

[5] Anwar, M. (2013). Educational Administration and Education Cost Management. Jakarta: Raja Grafindo Persada.

[6] Astuti, D. (2015). Education Quality Improvement Strategy. Jakarta: Rajawali Press.

[7] Hasbullah. (2012). Education Autonomy, Regional Autonomy Policies and Their Implications for Education Implementation. Jakarta: Raja Grafindo Persada.

[8] Kristiawan, M., Safitri, D., \& Lestari, R. (2017). Educational Management. Yogyakarta: Deepublish 
[9] Arikunto, S. (2010). Research Procedure A Practice Approach. Revised Edition. Jakarta: Rineka Cipta.

[10] Kemendiknas R. I. (2013). Education Quality Standards. Jakarta: Ministry of National Education of the Republic of Indonesia. 